\title{
Canine Babesioses in Noninvestigated Areas of Serbia
}

\author{
Simona Gabrielli, Suzana Otašević, ${ }^{2,3}$ Aleksandra Ignjatović,,4 Sara Savić, ${ }^{5}$ Maurizio Fraulo, \\ Valentina Arsić-Arsenijević, ${ }^{6}$ Stefan Momčilović, ${ }^{2}$ and Gabriella Cancrini ${ }^{1}$
}

\begin{abstract}
During the years 2012-2014, a total of 158 outdoor dogs from Pančevo and Đurđevo (northern Serbia) and Niš and Prokuplje (southern Serbia) were submitted to molecular analyses (PCR and sequencing) for canine babesioses. An overall prevalence of $21.5 \%$ was found, due to the species Babesia sp. 'spanish dog' (10.1\%), B. gibsoni $(5.7 \%)$, B. canis vogeli $(1.9 \%)$, B. caballi (1.9\%), and B. microti $(1.9 \%)$. In addition, sequence analysis showed the presence of Hepatozoon canis in a dog from Niš. No significant difference between infected and noninfected dogs was found by age, sex, and place of residence, whereas there was difference regarding the presence of ticks $(p<0.005)$ and application of preventive measures such as applying of antitick drugs/devices. Moreover, a significant difference was established by area: Dogs from Prokuplje showed infection rates (59.1\%) higher than dogs from Pančevo (11.9\%), Niš (4.5), and Đurđevo (where infected dogs were not found), and a different geographical distribution of the species was found. The presence of so many Babesia species and the first identification of $H$. canis will allow investigations on the pathogenic role played by each one and suggests entomological studies on the tick species that are more suitable vectors for each of them. Finally, the presence of so many infected dogs offers the opportunity of evaluating the hypothesis of a possible zoonotic role of babesial species affecting dogs.
\end{abstract}

Key Words: Babesiosis—Serbia—PCR—Dog.

\section{Introduction}

B ABESIOSES ARE WORLDWIDE EMERGING tick-borne diseases due to over 100 Babesia species that can infect various vertebrate hosts (Vannier et al. 2012), including occasionally humans. Dogs in Europe are mainly affected by Babesia canis, B. gibsoni, and B. canis vogeli (Irwin 2009), and they develop a malaria-like illness that ranges from asymptomatic infection to a fatal disease. Fever, jaundice, hemoglobinuria, and anemia are the common clinical signs of the disease (Conrad et al. 1991, Colly et al. 1992, Wozniak et al. 1997), whereas the serious form is characterized by splenomegaly, weakness, collapse, hypoxic injury, and systemic inflammation that can result in death. The most pathogenic species is $B$. canis, one of the species also reported in not well-documented cases of human infections (Gray 2006, Hunfeld et al. 2008, Gray et al. 2010, Vannier et al. 2012). It is cosmopolitan and transmitted primarily by Rhipicephalus sanguineus but also by Dermacentor reticulatus, ticks pres- ent in Serbia (Milutinović 1992), where geographical and climatic characteristics enable two generations of ticks/year (spring-autumn), and whose northern part is endemic for some babesial vector-intermittent hosts (Pavlović et al. 2002, Mihaljica et al. 2012, Milutinović et al. 2012).

Nevertheless, data on animal babesioses in Serbia are few and fragmentary; therefore, we started a study aimed at establishing species infecting dogs and their prevalence in four noninvestigated areas of the country. Research approved by the local Ethical Committee was performed using molecular diagnostics to identify Babesia species.

\section{Materials and Methods}

\section{Study areas}

In 2012-2014, a cross-sectional survey was organized in areas with moderate continental climate, characterized by hot and dry summers, severe winters, and relatively low precipitation. The first chosen areas were the northern territories

\footnotetext{
${ }^{1}$ Department of Public Health and Infectious Diseases, "Sapienza" University of Rome, Rome, Italy.

${ }^{2}$ Department of Microbiology and Immunology, Faculty of Medicine, University of Niš, Serbia, Niš, Serbia.

${ }^{3}$ Center of Microbiology and Parasitology, Public Health Institute Niš, Serbia, Niš, Serbia.

${ }^{4}$ Department of Medical Statistics, Faculty of Medicine, University of Niš, Serbia, Niš, Serbia.

${ }^{5}$ Scientific Veterinary Institute Novi Sad, Serbia, Novi Sad, Serbia.

${ }^{6}$ Department of Microbiology and Immunology, Faculty of Medicine, University of Belgrade, Belgrade, Serbia.
} 
of Pančevo $\left(44.86^{\circ} \mathrm{N} ; 20.64^{\circ} \mathrm{E}\right)$ and Đurđevo $\left(45^{\circ} 22^{\prime} \mathrm{N}\right.$; $20^{\circ} 04^{\prime} \mathrm{E}$ ), where programmed hematological controls by microscopy, carried out in the past by local veterinary practitioners, have detected babesiae in dogs. Then, we selected the southern territories of Prokuplje $\left(43.24^{\circ} \mathrm{N} ; 21.59^{\circ} \mathrm{E}\right)$ and Niš $\left(43.19^{\circ} \mathrm{N} ; 21.54^{\circ} \mathrm{E}\right)$, from which no information about babesiosis were available (Fig. 1).

\section{Dog population}

A total of 158 dogs were screened for the presence of Babesia (79 males and 79 females, aged 3 months to 14 years). A first group of 125 privately owned dogs was randomly enrolled in the study areas using the following criteria: (1) Never moved outside the study area; (2) healthy, asymptomatic; (2) kept in the open; and (4) not protected with antitick drugs/devices, nor treated with chemo-prophylactic drugs. In addition, 33 dogs kept in a dog shelter in Đurđevo, in partial control-life conditions and with antitick drugs/ devices applied to their skin, were included in the survey. Blood was extracted from the earlobe of each animal after cutting the hair, shaving, and disinfecting the area, and placed on (300-500 $\mu \mathrm{L})$ filter papers for molecular analyses.

\section{Molecular analyses}

DNA was extracted from dried blood spots using a commercial kit (Nucleospin Tissue, Mackery-Nagel, Duren, Germany) following the manufacturer's instructions. To detect the presence of babesial parasite DNA, PCR was performed using the primers CRYPTO $\mathrm{F}$ (5'-AACCTGGTTGATCCTGC CAGT-3') (Herwaldt et al. 2003) and RLB-R2 (5'-CTA AGA ATT TCA CCT CTG ACA GT-3') (Georges et al. 2001) that amplify a fragment of approximately $800 \mathrm{bp}$ of the piroplasm $18 \mathrm{~S}$ ribosomal RNA. Amplification products were electro-

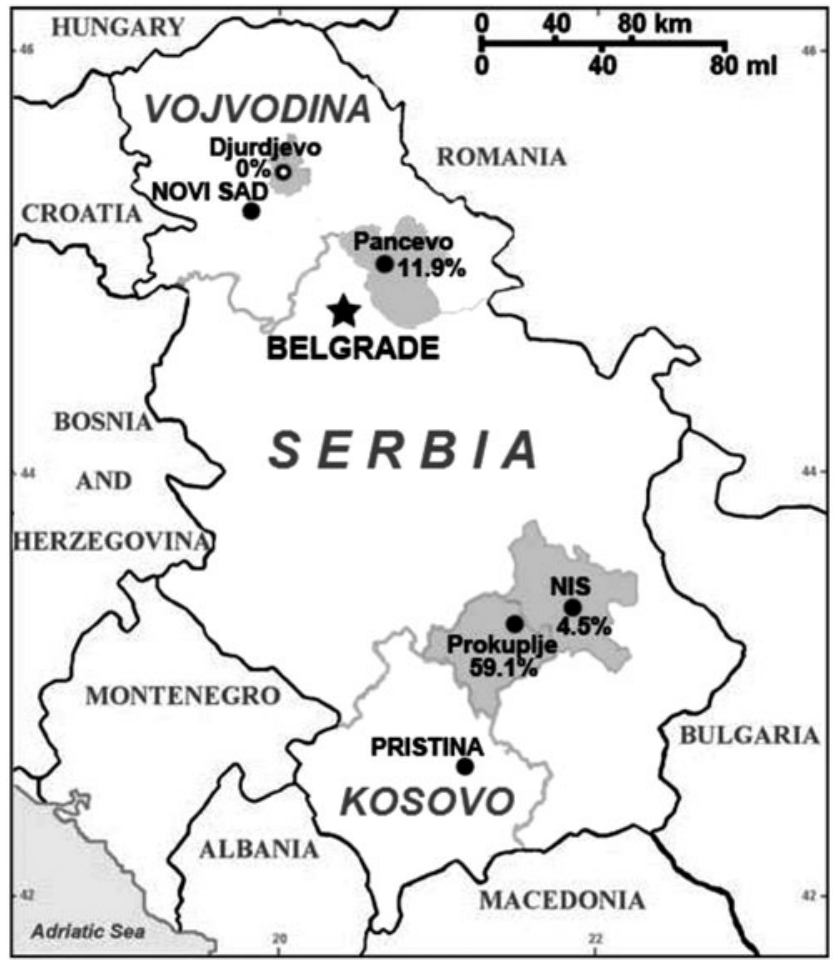

FIG. 1. Map of Serbia showing study areas with prevalence. phoresed in $1.5 \%$ agarose gel stained with $5 \mu \mathrm{g} / \mathrm{mL}$ ethidium bromide. Amplicons were purified using the SureClean Kit (Aurogene, Rome, Italy) following the manufacturer's instructions and directly sequenced with PCR primers in both directions by an external sequencing core service (Eurofins MWG Operon, Anzinger, DE). Sequences obtained were corrected by visual analysis of the electropherograms, aligned using the ClustalW program, and compared among them and with those available in the GenBank dataset by BLAST analysis.

\section{Statistical analyses}

Data are presented as mean and standard deviation, or percent frequency, with $p=0.05$ indicating statistical significance. Categorical variables were analyzed by chi-squared or Fisher exact tests. Statistical analysis of data was performed using the R 2.15.3 software (R Foundation for Statistical Computing, Vienna, Austria; www.R-project.org/).

\section{Results}

The overall prevalence of babesiosis in the dog population was $21.5 \%$ (34/158), and species identified by sequencing are the following: Babesia sp. 'spanish dog' (10.1\%) (acc. no. FJ608737.1), B. gibsoni (5.7\%) (JX110650.1), B. canis vogeli (1.9\%) (AF547387), B. caballi (1.9\%) (AY346370), and B. microti (1.9\%) (KJ649294). Table 1 summarizes the epizootic characteristics of positive and negative subjects. Positive dogs were younger; nevertheless, no significant difference by age, sex, and place of residence was found between Babesia-infected and noninfected dogs. A significant difference was established regarding the presence of ticks $(p=0.002)$ and life condition of dogs $(p=0.001)$. The higher percent of positive dogs had tick ectoparasitosis, and no infected dog was found in the group of subjects protected with antitick drugs/devices.

Moreover, a difference $\left(\chi^{2}=27.827, p<0.001\right)$ was found between infection rate evidenced in the animals resident in the examined areas (Table 2): Dogs coming from the southern territory of Prokuplje showed an extremely high prevalence $(59.1 \%)$, followed by dogs from Pančevo (11.9\%) and Niš $(4.5 \%)$. We did not find any infected dog from Đurđevo. In the territory of Prokuplje, the most prevalent species was Babesia sp. 'spanish dog' (36.4\%), followed by B. gibsoni $(18.2 \%)$ and $B$. microti $(4.5 \%)$, whereas in the territory of Pančevo $B$. caballi and $B$. canis vogeli were more prevalent (5.1\%) than B. gibsoni (1.7\%). In Niš, B. microti was detected in $4.5 \%$ of dogs. Therefore, the species identified in the three areas were almost entirely different: Babesia sp. 'spanish $d o g$ ' was exclusively found in Prokuplje, and B. canis vogeli and $B$. caballi exclusively in Pančevo. On the contrary, B. gibsoni was identified in both the aforementioned cities, although at significantly different prevalences $(18.2 \%$ vs. $1.7 \%$ ), and B. microti both in Prokuplje and in Niš. Finally sequence analysis showed the presence of Hepatozoon canis (JF827276.1) in a $\operatorname{dog}(4.5 \%)$ from Niš.

\section{Discussion}

The cross-sectional survey clearly shows that three investigated territories are endemic for canine piroplasmoses due to many species. These results, adding new tesserae to the complex mosaic of the infection, contribute to a better 
Table 1. Epizootic Characteristics of Dogs Examined

\begin{tabular}{lccc}
\hline & $\begin{array}{c}\text { Babesia- } \\
\text { positive } \\
\mathrm{n}=35\end{array}$ & $\begin{array}{c}\text { Babesia- } \\
\text { negative } \\
\mathrm{n}=123\end{array}$ & $\mathrm{p}$ \\
\hline Age (months) & $35.29 \pm 27.96$ & $47.49 \pm 40.46$ & $0.221^{*}$ \\
Sex (male/female) & $18 / 17$ & $61 / 62$ & $0.848^{* *}$ \\
$\begin{array}{c}\text { Presence of ticks } \\
\text { Place of residence } \\
\text { (rural/urban) }\end{array}$ & $19(54.28)$ & $\begin{array}{c}31(25.20) \\
0.002^{* *}\end{array}$ \\
$\begin{array}{c}\text { Anti-tick drugs/ } \\
\text { devices protection }\end{array}$ & 0 & $60 / 63$ & $0.495^{* *}$ \\
\hline
\end{tabular}

*Mann-Whitney test.

**Chi-squared test.

***Fisher's test.

knowledge of the epidemiology of these zoonoses in Serbia. Available data indicate that in 80 years of the past century in the Belgrade district dog babesiosis was a sporadic infection detected only in hunting dogs and in pets after vacations (Krstić et al. 1994, Potkonjak et al. 2014). However, at the beginning of this century, this epizootic scenario is deeply changed: The aforementioned area became hyperendemic (overall prevalence $\approx 74 \%$; Pavlović et al. 2002), so that in territories of Belgrade and Vojvodina (which include the city of Pančevo and Đurđevo village), research on vector-borne zoonoses and plans of control programs were started (Savić et al. 2014). Veterinary practitioners, as part of the routine work, now examine the peripheral blood of animals to detect and pharmacologically treat babesial parasites. Therefore, in Pančevo, included in territories now under control, we found infection rates significantly lower than in Prokuplje, and even lower than in the territory of Belgrade, probably because only asymptomatic dogs were enrolled in this study. Control programs in the Đurđevo asylum included annual parasitological analyses of peripheral blood and use of antitick protection devices (applied to the skin of dogs), which explains why we did not find any Babesia-infected asymptomatic dog.

This is the first research study in southern Serbia, and its results point out a very high prevalence of canine babesioses, demonstrating the need to continue monitoring of the resident dogs. As for the species found, B. gibsoni was the only species in both areas. Until recently, this species was described in Asia, including Japan, and only sporadically has it been found worldwide, primarily in fighting dogs (Irwin 2009), in which it can be directly transmitted dog-to-dog during dog fights (Imre et al. 2013). However, neither fighting dogs nor Pit Bull Terriers were included in our study.

$B$. microti, usually a parasite of rodents and so far considered as a single species, is present in both considered southern areas, and in one of them (Prokuplje) sympatric with Babesia sp. 'spanish dog', the species belonging to the same complex and parasite of carnivores (Hunfield et al. 2008). It is useful to remember the zoonotic potential of B. microti, which is the predominant cause of human babesiosis in the United States and a rare cause of disease in Europe and Asia. The infection in immunocompetent persons may run subclinically or cause mild symptoms, whereas it can be life threatening in immunocompromised individuals, including infants. Recent serological studies carried out in Italy (Gabrielli et al. 2014) found an unexpected high reactivity to B. microti antigens in people at risk of infection $(11.7 \%$ in hunters and $32 \%$ in foresters), which is greater than the ones reported in Poland (4.4\% in foresters) (Pancewicz et al. 2011), in eastern Switzerland (1.5\%) (Foppa et al. 2002), and in Germany (1.7\%) (Hunfeld et al. 2002). Therefore, our findings suggest the possible occurrence of cases of human babesial infections in Serbia, and we alert physicians to consider these otherwise neglected parasitic diseases when dealing with any febrile illness, especially in subjects exposed to tick bites.

B. canis vogeli, only found in territories of Pančevo, has worldwide distribution and is common in European Mediterranean countries. B. caballi, identified in the same territories and a parasite of horses and donkeys from tropic and subtropic areas, is spreading to the Mediteranean region and, recently, has been detected in dogs from endemic zones (Qablan et al. 2012, Gallusova et al. 2014).

In Serbia, canine babesiosis to date has been ascribed to B. canis (Tomanović et al. 2013); however, considering that neighboring countries are endemic for babesiosis, high prevalence of the infection and the presence of many species were expected. Indeed, in Hungary B. canis (Földvári et al. 2005), Romania B. canis and B. vogeli (Ionita et al. 2012), and Croatia B. canis canis, B. gibsoni, and B. canis vogeli (Beck et al. 2009) have been reported. Therefore, we found even more than the expected species in Serbian dogs. These results are interesting because knowing the geographical distribution of Babesia species and subspecies is important primarily to complete their mapping in Europe and to define the endemic areas and their autochthonous strains. Indeed, only on this basis we can recognize changes in ecological

Table 2. Babesia Species Identified in Dogs from Territories of Northern and Southern Serbia

\begin{tabular}{|c|c|c|c|c|c|c|}
\hline \multirow[b]{2}{*}{ Species } & \multirow[b]{2}{*}{ Total } & \multirow{2}{*}{$\frac{\text { Northern }}{\text { Pančevo }}$} & \multicolumn{2}{|c|}{ Southern } & \multirow[b]{2}{*}{$\mathrm{p}^{*}$} & \multirow{2}{*}{$\underset{\%}{\text { Identity }}$} \\
\hline & & & Prokuplje & $N i \check{s}$ & & \\
\hline Babesia sp.'spanish dog, & $16 / 158$ & $0 / 59$ & $16 / 44$ & $0 / 22$ & $<0,001^{\dagger}$ & 91 \\
\hline B. gibsoni & $9 / 158$ & $1 / 59$ & $8 / 44$ & $0 / 22$ & $<0,001^{\dagger}$ & 100 \\
\hline B. canis vogeli & $3 / 158$ & $3 / 59$ & $0 / 44$ & $0 / 22$ & $0,496^{\dagger}$ & 99 \\
\hline B. caballi & $3 / 158$ & $3 / 59$ & $0 / 44$ & $0 / 22$ & $0,496^{\dagger}$ & $96-99$ \\
\hline B. microti & $3 / 158$ & $0 / 59$ & $2 / 44$ & $1 / 22$ & $0,282^{\dagger}$ & 91 \\
\hline Total & $35 / 158$ & $7 / 59$ & $26 / 44$ & $1 / 22$ & $0,001^{\ddagger}$ & \\
\hline Prevalence & $22.2 \%$ & $11.9 \%$ & $59.1 \%$ & $4.5 \%$ & & \\
\hline
\end{tabular}

*Prokuplje vs Pančevo and Niš.

${ }^{\dagger}$ Fisher's test.

Chi-squared test. 
ranges and vector migration and, mainly, prevent their spread in the free zones, a danger increasingly concrete due to the increased vacation travel on with pets or their use for hunting. Moreover, these results are useful because the production of sensitive and specific immunological tests and vaccines to diagnose and prevent the infection in animals as well as in humans requires detailed knowledge about the local ecology/ distribution of each species.

The very high prevalence of babesioses and the first finding of $H$. canis in dogs in southern Serbia established in this survey necessitate intensifying epidemiological and epizootic studies that are aimed at promoting appropriate control programs (continuing education, diagnosis, and treatment primarily included) to protect dogs. In addition, the presence of so many species will allow investigations on the pathogenic role played by each one and entomological observations on the tick species that are the more suitable vector for each of them. Finally, the presence of so many infected dogs offers the opportunity of evaluating the hypothesis of a possible zoonotic role of babesial species affecting dogs and is an alert on the concrete direct and indirect threats to the public health due to the finding of B. microti in southern areas of the country. Indeed, infection in humans may be undetected or misdiagnosed and, furthermore, the presence of the parasite in the blood of asymptomatic subjects is of concern for the possible risk of transfusion-associated transmission.

\section{Author Disclosure Statement}

No competing financial interests exist.

\section{References}

Beck R, Vojta L, Mrljak V, Marinculić A, et al. Diversity of Babesia and Theileria species in symptomatic and asymptomatic dogs in Croatia. Int J Parasitol 2009; 39:843-848.

Colly LP, Nesbit JW. Fatal acute babesiosis in a juvenile wild dog (Lycaon pictus). J S Afr Vet Assoc 1992; 63:36-38.

Conrad P, Thomford J, Yamane I, Whiting J, et al. Hemolytic anemia caused by Babesia gibsoni infection in dogs. J Am Vet Med Assoc 1991; 199:601-605.

Földvári G, Hell E, Farkas R. Babesia canis canis in dogs from Hungary: Detection by PCR and sequencing. Vet Parasitol 2005; 127:221-226.

Foppa IM, Krause PJ, Spielman A, Goethert H, et al. Entomologic and serologic evidence of zoonotic transmission of Babesia microti, eastern Switzerland. Emerg Infect Dis 2002; 8:722-726.

Gabrielli S, Calderini P, Cassini R, Galuppi R, et al. Human exposure to piroplasms in Central and Northern Italy. Vet Ital 2014; 50:41-47.

Gallusová M, Qablan MA, D’Amico G, Oborník M, et al. Piroplasms in feral and domestic equines in rural areas of the Danube Delta, Romania, with survey of dogs as a possible reservoir. Vet Parasitol 2014; 206:287-292.

Georges K, Loria GR, Riili S, Greco A, et al. Detection of haemoparasites in cattle by reverse line blot hybridization with a note on the distribution of ticks in Sicily. Vet Parasitol 2001; 99:273-286.

Gray J, Zintl A, Hildebrandt A, Hunfeld KP, et al. Zoonotic babesiosis: Overview of the disease and novel aspects of pathogen identity. Ticks Tick Borne Dis 2010; 1:3-10.

Gray JS. Identity of the causal agents of human babesiosis in Europe. Int J Med Microbiol 2006; 296:131-136.
Herwaldt BL, Cacciò S, Gherlinzoni F, Aspöck H, et al. Molecular characterization of a non-Babesia divergens organism causing zoonotic babesiosis in Europe. Emerg Infect Dis 2003; 9:942-948.

Hunfeld KP, Lambert A, Kampen H, Albert S, et al. Seroprevalence of Babesia infections in humans exposed to ticks in midwestern Germany. J Clin Microbiol 2002; 40:2431-2436.

Hunfeld KP, Hildebrandt A, Gray JS. Babesiosis: Recent insights into an ancient disease. Int J Parasitol 2008; 38:1219-1237.

Imre M, Farkas R, Ilie MS, Imre K, et al. Survey of babesiosis in symptomatic dogs from Romania: Occurence of Babesia gibsoni associated with breed. Ticks Tick Borne Dis 2013; 4:500-502.

Ionita M, Mitrea IL, Pfister K, Hamel D, et al. Canine babesiosis in Romania due to Babesia canis and Babesia vogeli: A molecular approach. Parasitol Res 2012; 110:1659-1664.

Irwin PJ. Canine babesiosis: From molecular taxonomy to control. Parasit Vectors 2009; 2:S4.

Krstić V, Trailović D, Andrić N, Čalić M, et al. Contribution to epizootiology of dog babesiosis in Belgrade area. Proceedings of the $7^{\text {th }}$ Conference of Veterinarians Of Serbia, September 1316; 1994. Zlatibor, Yugoslavia. Belgrade: Veterinary Chamber of Serbia, 1994.

Mihaljica D, Radulović Ž, Tomanović S, Ćakić S, et al. Molecular detection of Babesia spp. in ticks in Northern Serbia. Arch Biol Sci 2012; 64:1591-1598.

Milutinović M. Ekološka istraživanja krpelja (Acarina, Ixodoidea, Ixodidae) Srbije [dissertation]. Beograd, Srbija: Biološki fakultet Univerziteta u Beogradu, 1992.

Milutinović M, Radulović Ž, Tomanović S, Petrović Z. Krpelji (Acari: Ixodidae, Argasidae) Srbije, $1^{\text {st }}$ ed. Belgrade: Serbian Academy of Sciences and Arts, 2012.

Pancewicz S, Moniuszko A, Bieniarz E, Puciło K, et al. AntiBabesia microti antibodies in foresters highly exposed to tick bites in Poland. Scand J Infect Dis 2011; 43:197-201.

Pavlović I, Milutinović M, Petković D, Terzin D, et al. Epizootiological research of canine babesiosis in the Belgrade district. J Protozool Res 2002; 12:10-15.

Potkonjak A, Savić S, Spasojević-Kosić L, Vračar V, et al. Findings of antibodies for Rickettsia conorii and Babesia canis in hunting in Vojvodina. Proceedings of the $25^{\text {th }}$ Conference of Veterinarians Of Serbia; Sept 11-14, 2014, Zlatibor, Serbia. Belgrade: Serbian Veterinary Society, 2014.

Qablan MA, Kubelová M, Siroký P, Modrý D, et al. Stray dogs of northern Jordan as reservoirs of ticks and tick-borne hemopathogens. Parasitol Res 2012; 111:301-307.

Savić S, Vidić B, Grgić Ž, Potkonjak A, et al. Emerging vectorborne diseases-incidence through vectors. Front Public Health 2014; 2:267.

Tomanović S, Chochlakis D, Radulović Z, Milutinović M, et al. Analysis of pathogen co-occurence in host-seeking adult hard ticks from Serbia. Exp Appl Acarol 2013; 59:367-376.

Vannier E, Kraus JP. Human Babesiosis. N Engl J Med 2012; 366:2397-2407.

Wozniak EJ, Barr BC, Thomford JW, Yamane I, et al. Clinical, anatomic, and immunopathologic characterization of Babesia gibsoni infection in the domestic dog (Canis familiaris). J Parasitol 1997; 83:692-699.

Address correspondence to: Suzana Otašević $8 / 25$, Pasterova street $18000 \mathrm{Niš}$ Serbia

E-mail: otasevicsuzana@gmail.com 